DOI 10.18551/rjoas.2021-05.21

\title{
THE PRACTICE OF IDENTITY POLITICS IN THE BANGKA BELITUNG REGIONAL HEAD ELECTION
}

\author{
Amir Amir* \\ Postgraduate Study Program of Sociology, Makassar State University, Indonesia \\ Salman Darmawan, Fahmid Imam Mujahidin \\ Study Program of Agriculture, Hasanuddin University, Indonesia
}

*E-mail: amirdedoee@gmail.com

\begin{abstract}
The practice of identity politics built through a regime of power is part of a social fact that has grown more widely in various regions in Indonesia, especially post-reformation. The difference between identity politics in Indonesia is essential to study to maintain political stability. The phenomenon of strengthening identity politics is explicitly found in the Province of Bangka Belitung Islands. This study aims to analyze the Practice of Identity Politics in the Pilkada of Bangka Belitung. This research uses a qualitative approach. This research was conducted in the Province of Bangka Belitung Islands. The research results show that the people of Bangka Belitung as a multi-ethnic community in their daily life before the election live in a harmonious atmosphere. Enter the post-conflict local election period, inter-ethnic relations, especially between local indigenous groups, native immigrants, and Chinese ethnic groups, were divided into ethnic groups based on primordial sentiments. The ethnic identities of the people of the Bangka Belitung Islands Province can be grouped into three groups. The three groups include the indigenous ethnic group, the indigenous immigrant ethnic group, and the Tinghoa ethnic group. In the political context in a multi-ethnic region, especially in the post-conflict local election / legislative election contestation, identifying ethnic identity is imperative. Actor in the arena to win the ethnic identity battle becomes a strategy in contestation. Factors supporting actors in winning the battle to gain power, maintain, and even expand power in the arena must be supported by capital, a cultural capital, or symbolic capital and take advantage of primordial sentiments.
\end{abstract}

\section{KEY WORDS}

Politics, identity, power, public relations.

The change from the New Order era to the Reform era has changed the view of Indonesian society about ethnic and religious identities. The revival of regional identity and political awareness has only occurred to reconstruct local wisdom values based on primordial ethnicity and religion. In Indonesia, identity politics is more related to ethnicity, religion, ideology, and the interests of local elites, which are articulated through regional expansion (Sjaf 2014). Indonesia consists of approximately 13,677 islands, both large islands and small island clusters (BPS 2017). Of the many islands inhabited by ethnic groups and sub-ethnic groups or clans different from one another. The cultural pluralism that can be found on the islands of Indonesia, coupled with ethnic groups and clans that are culturally different, makes the Indonesian archipelago a culturally diverse and heterogeneous country. The emergence of identity politics in Indonesia's very diverse political dynamics is inseparable from the sense of injustice and equal rights claimed by each particular group or social group.

Identity politics is interpreted as using all ascriptive identities (ethnic, religious, and other) in the competition for political and socio-economic resources (Esman 1994; van linked 2007; Thung et al. 2010; Aspinall 2011). Identity is a sign of biological evidence and a distinctive feature that differentiates between other ethnicities. Even though it grows and develops in one area, identity has always been a differentiator and even has links between the past and the present (Smith, 2012). This distinguishing aspect shows an ethnic group 
called "ethnic ideology" (Levine Campbell; 1972). The difference between identity politics in Indonesia is essential to study to maintain political stability. As a nation with many ethnic groups, religions, races, languages, and customs, Indonesia is faced with various challenges that are certainly not young in mixing existing diversity. The political life of the Indonesian nation is faced with the diversity of its ethnic groups. As with the community groups in the Bangka Belitung Islands, they are faced with the diversity of existing ethnic groups. Sjaf (2014) also explains that the practices of ethnic domination are divided into three practices of domination of power, namely the practice of symbolic power domination, the practice of dominating economic power, and the practice of dominating political power. The phenomenon of strengthening identity politics is explicitly found in the Province of Bangka Belitung Islands. The strengthening of identity politics in the local political arena is due to the shift in the centralized government system towards decentralization. According to Ruman (2011), in the era of decentralization, local elites saw this political opportunity as an opportunity for claims to protect religion, culture, and local identity, as a phenomenon of identity politics that almost did not occur in the muscle system during the New Order era. States that in the era of decentralization, the position of regional heads is powerful in power from all fronts, political, social, and even economic (Ruman 201).

Political actors of the Bangka Belitung Islands Province in the political stage can be mapped based on local indigenous actors, native immigrants, and ethnic Chinese. In elections for regional heads, the emergence of political actors representing three ethnic groups. Each ethnic group such as local indigenous groups, native immigrants, and ethnic Chinese groups. Each of the ethnic groups in the relationship to seize, maintain and even expand power plays the symbols of ethnicity, race, religion, and the group as an identity group. Based on the composition of the population according to the ethnic group of the people of the Bangka Belitung Islands Province, in terms of quantity, the Malay ethnic group as local pribumi occupies the first position with a total of $71.89 \%$, the native immigrant group occupies the second position with $17.01 \%$, and the Chinese ethnic group ranks first. The third with the amount of $11.10 \%$. Therefore, this research aims to analyze the practice of identity politics in the Bangka Belitung regional election.

\section{LITERATURE REVIEW}

The theoretical study in this research will use a post-structuralist perspective as the leading theory through Pierre Bourdieu's theoretical approach to habitus, arena, and capital. Bourdieu's thoughts on arenas, capital, and habitus emphasize the ongoing formation of identity politics and contestation in the political arena and describe the impact of the political process. In various arenas, economic, social, and cultural as well as discovering patterns of identity politics. Bourdieu's social practice theory will later describe the domination of local politics in the same ethnic context, not in the inter-ethnic realm. Then, mapping through a political culture that operates in socio-historical conditions in the perspective of actors and structures. The mapping of this theory is an effort to analyze and decipher the research problem into a specific form in the social formation of the community in the study location. 10 In addition, Bourdieu's primary theoretical approach is also assisted by essential concepts of identity politics, politics, and development to enrich the commentary in the study literature review on this research. Bourdieu's theory has two peculiarities between the dichotomy of individual and society, agent-structure and freedom-determinism. First, critical theories regarding habitus, arenas, and capital can be used to identify the assumed domination of society by tracing the accumulation of ownership of capital in society. Second, this distinctive approach has become the main foothold for Bourdieu in explaining various phenomena. Instead, it is used to dismantle or analyze the domination of power practices in various domains (arenas) starting from the realm of politics, culture, and so on (Krisdinanto 2014). For Bourdieu, the assumed domination is about the economy and the domination of ethnicity, political culture, gender, and so on in various areas. Bourdieu also puts his analysis on symbolic domination [the practice of power in the context of symbols]. Second, this distinctive perspective of Bourdieu's thought can be used to explain various phenomena, the practice of 
power that exists in various areas (political, social, cultural, etc.), and even the basis of analysis that Bourdieu has developed can trace the domination interests of the role of culture. , consumptive] and ideology (Krisdinanto 2014: 190). To maintain the existence of an actor in a particular arena, an actor must have the power and the actor's way of maintaining his existence in the arena. The arena is defined as a dynamic area where there are struggles to get certain positions if capital is the power of an actor or position in a social structure that is determined by the capitals he has, while habitus 13 is defined as a cognitive mental structure used by actors to face their social life (Bourdieu 2010; Sjaf 2014). Social, economic, cultural, and political arenas are seen as forms of discourse supporting actors' gaining power. Thus, it is increasingly clear that the linkage of ethnic identities continues to operate in the cycle of the arena, capital, and habitus. Apart from that, ethnic identity is used in various interests, be it social, religious, cultural, economic, and political arenas. So the inter-ethnic relations, ethnic domination tends to lead to those [actors] benefit and dis advantaged, mainly due to the political process [power]. For Bourdieu, an agent [individual or institution] position in the social structure is determined by the assets it has (Huber et al. 1999; Alamsyah 2009). Four types of capital determine the agent's position: economic capital, cultural capital, social capital, and symbolic capital (Boourdie 1992; Alamsyah 2009). The political process is an "arena" when actors [political elites] who are fighting for political power are always supported by economic capital [material wealth], cultural capital [position in society, prestige, knowledge, skills], social capital [networks, connectivity] and symbolic capital [cultural symbols [of the same ethnicity] which can strengthen the position of the agent].

\section{METHODS OF RESEARCH}

This study intends to understand how political actors in the Province of Bangka Belitung Islands participate in group politics from various ethnic groups, mapped into 3 (three) categories: local natives, native immigrants, and ethnic Chinese. These three ethnic groups contest on the arena stage to gain, maintain, and even expand power. Thus, the relevant paradigm as the basis for the research is the constructivism paradigm, which aims to reach consensus or at least a negotiation agenda on various issues and topics that explain the nature of research. Lincolm (in Denzim \& Lincolm 2011). The research approach used is qualitative. This approach was chosen with the consideration that through a qualitative approach, researchers can understand (verstehen) the processes, meanings, and outcomes of identity politics in Bangka Belitung. This research was conducted in the Province of Bangka Belitung Islands. The data obtained in this study are data about ethnic identities and actors. The key informants in this study consisted of political figures, party administrators, each from local natives, native immigrants, and ethnic Chinese. The data collection techniques used were observation, interview, snowball sampling technique, and documentation study. The validity of the data was carried out using the triangulation technique of sources, methods, investigators, and theories (Denzin \& Lincoln, 2011). The data analysis technique used is the flow data analysis model (Miles \& Huberman, 2018).

\section{RESULTS AND DISCUSSION}

The plurality of Indonesian society, where each ethnic group maintains a homogeneous ethnic identity, has a strong relationship in social life activities. The phenomenon of ethnicity itself appears in social interactions that affect the relationship between individuals and groups, with their social and natural environment (Suparlan 2003). In line with this explanation, Sjaf (2014) explains that ethnic identity is a social product that contains relational concepts related to self-identification (subjectivity) and social origins (objectivity). According to Schultz and Lavenda (2001) articulation, it is explained that ethnic identity is created by a historical process that combines different social groups into a single political structure under certain social conditions. Thus, it can be concluded that there is the strength of ethnic identity, which is the power inherent in ethnicity and used as a means for actors to 
organize or mobilize the masses in the arenas of life, such as social, economic, and political. This power is also used in dominating practices over other groups in obtaining more benefit from existing resources.

The practice of identity politics in society is formed through the political power built by political actors who fight in regional head elections. Ethnic identity becomes a strategy for actors in the lead-up to general elections, especially post-conflict local elections such as the governor-duty governor or the Election for the Regent and the Deputy Regent to win the battle for power. Candidate pairs in contestation to win the battle in the post-conflict local election, the configuration of the Bangka-Belitung Island pair is absolute. The dynamics of ethnic identity politics are shown in the implementation of the Regional Head Election in Bangka Belitung Islands Province, such as the Regional Head Election for Governor and Deputy Governor, Regional Head Election for Regent and Deputy Regent in Bangka Belitung Islands Province. The direct Regional Head General Election (Pemilukada) in Bangka Belitung has been held three times since the era of Regional Autonomy (Reform), the first was held in 2002, and the second was held in 2007. The election results for DPD-RI members for the Bangka Belitung electoral district from the period In 2004-2019, several names of actors appeared representing local indigenous ethnic groups, native immigrants, and Chinese ethnic groups. Local indigenous ethnic groups. For example, the name of the actor, represented by Drs. H. Rusli Rahman, M.Si., the native immigrant group appears the name of the actor represented by Jamilah's mother. The election for the $2009-2014$ period emerged three ethnic groups. From the local pribumi emerged actors such as Drs. $\mathrm{H}$. Rosman Djohan. The indigenous group of immigrants appeared $\mathrm{Hj}$. Noorhari Astuty, S.Sos. At the same time, representatives of the Chinese ethnic group appeared as actors on Telly Gozellie, SE, and Bahar Busan, ST. Likewise, for the election results for 2014 - 2019, there were local indigenous actors and Chinese ethnic groups such as Drs. HA. Hudarni Rani, SH, Herry Erfian, ST, Telly Gozelli, and Bahar Busan, the last two names each representing the Chinese ethnic group. Sjaf (2014) said that identity politics in a pluralistic society consisting of different identity backgrounds, be it ethnicity, religion, race, or gender, is a social construction of a society that cannot be ruled out. The upheaval of identity politics (identity awakening) will always be linked to different conflicts of interest in society. In fact, what is happening now is the increasing cultural differences due to the culture of a particular ethnicity (indigenous vs. immigrant ethnicity). Ethnic identities are now changing into identities in the sense of "new," not just social identities. The people of Bangka Belitung as a multi-ethnic community in their daily life before the election lived in a harmonious atmosphere. Over time, when entering the post-conflict local election period, inter-ethnic relations, especially between local indigenous groups, native immigrants, and ethnic Chinese, were divided into ethnic groups based on primordial sentiments.

Table 1 - Actors by local groups

\begin{tabular}{|c|c|c|c|c|c|c|c|c|c|}
\hline \multirow{2}{*}{ No } & \multirow{2}{*}{ Actor } & \multicolumn{3}{|l|}{ Pulau Bangka } & \multirow{2}{*}{-Actor } & \multicolumn{3}{|c|}{ Pulau Belitung } & \multirow[t]{2}{*}{ Information } \\
\hline & & Group & Religion & Race & & Group & Religion & Race & \\
\hline 1 & Hudarni Rani & Melayu & Islam & Deutro Melayu & Suryadi Saman & Melayu & Islam & Deutro Melayu & Period I \\
\hline 2 & Eko Maulana Ali & Melayu & Islam & Deutro Melayu & Rustam Efendi & Melayu & Islam & Deutro Melayu & Period II \\
\hline$\beta$ & Hidayat Arsani & Etnik Tionghoa & Islam & Mongoloid & Rustam Efendi & Melayu & Islam & Deutro Melayu & Transition \\
\hline 4 & Erzaldi Rosman & Melayu & Islam & Deutro Melayu & Abdul Fatah & Melayu & Islam & Deutro Melayu & Period III \\
\hline
\end{tabular}

Regional Head Election implementation in Bangka Belitung Islands Province such as Governor and Deputy Governor Election, Regent and Deputy Regent Election in Bangka Belitung Islands Province during the three regional elections for the first period of 2002-2007 was Mr. Hudarni Rani; SH is one of the political actors from the party elite. Golongan Karya delegates from Bangka Level II regional representatives. As the partner of Mr. Hudarni Rani, $\mathrm{SH}$ is Mr. Suryadi Saman representing from the Level II area of Belitung. Following the second period as a result of the democratic party in the General Election for $2007-2012$ is the pair promoted by the Golongan Karya Party (Golkar) in a coalition with the Indonesian Democratic Party of Struggle (PDIP) with the partner Dr. Ir. Eko Maulana Ali, M.Sc with Mr. Rustam Efendi, B.Sc as representatives based on regions, namely Bangka and Belitung. In 
the course of Mr. Eko Maulana Ali's leadership, because he died due to kidney failure, the position of Mr. Eko Maulana Ali as governor was held by his deputy Mr. Rustam Efendi as governor of Bangka Belitung and who sat alongside Mr. Rustam Efendi as the deputy was Mr. Hidayat Arsani. The latter was appointed by acclamation from his party, namely Group of Work (Golkar). Mr. Hidayat Arsani, emotionally based on his ethnic group, becomes a representation of the Chinese ethnic group. The process of practicing identity politics often puts forward the sentiment of groups with the same identity to achieve a specific goal. Abdillah (2002: 1-9) states that the emergence of identity politics itself is due to the failure of modernity as an agent of development and change that is incompatible with the culture of a plural society. Identity politics is the result of previous changes due to modernization which brings together natural [ethnic] identities in various areas of life (Sjaf 2014: 170). Furthermore, identity politics is a collective form of elite patronage based on family relations, ethnicity, and blood relations and has led to monarchical democracy at the local level (Djati, 2013: 204-205). According to Sarumpaet (2012), if local elites use structurally framed communities to gain power through political processes, they tend to mobilize networks through ethnic identities deliberately created to win battles, primarily regional head elections.

Political Participation of Various Ethnic Groups in the Regional Head Election of Bangka Belitung. Politics is always synonymous with power; it can even be said that everything that leads to power in politics. In general, power can influence other people to act according to their wishes even though that person does not necessarily like it. In democracy at the local level, especially in direct regional head elections, it has been shown that ethnicity is very dominant and influences candidates in attracting the masses to gain political power in gaining support from the community. Because in the context of identity politics, ethnicity is a vital force to gain power. In the context of political power, it must be used to benefit many people, not individuals. On the other hand, identity politics is the power obtained by influencing and convincing others based on primordial sentiments.

In a democratic country, ethnic, cultural identity does not disappear and usually dissolves in various existing political institutions. This condition encourages a movement to strengthen an ethnic culture that is politically oriented. General Election (Pemilukada), both Pemilukada and Pileg. The situation in inter-ethnic relations has become sharp from the various ethnic groups that are polarized into groups based on region, ethnicity, and religion. The political participation of the three ethnic groups in the post-conflict local election / regional election in Bangka Belitung.

The political participation of the three categories of ethnic groups, both local pribumi, native immigrants, and ethnic Chinese, shows a difference. The differences that exist can be seen from the time before the Pilkada / Pilleg took place until just before the General Election / Pileg took place. This trend can be seen in the picture of the relationship between the three ethnic groups, where the pattern of relationships between the existing ethnic groups is solid between one another before implementing the General Election. However, in the lead-up to the post-conflict local election / legislative elections, the pattern of relations between the three ethnic groups is polarized into groups based on regional, ethnic, racial, and religious sentiments as in the picture above. From the interview results, the communication and interaction between ethnic groups in the Bangka Belitung Islands are pretty harmonious. The relationship between local indigenous groups, immigrants, and ethnic Chinese groups is quite good. However, unfortunately, the harmonious atmosphere among the existing ethnic groups changed immediately before implementing the Regional Head Election / Pilleg in the province of Bangka Belitung Islands.

The pattern of relationships is sharpened by differences between groups based on regional sentiments according to ethnicity, race, and religion. There is a sharper relationship between ethnic Chinese groups, whose identities vary according to race, language, and religion between local natives and immigrant natives. The same thing happened to the local indigenous groups against the immigrant pribumi; primordial sentiments emerged. The dominant terms "ka," "Ku," "kite," and them, means you are in a relationship with me, and we are in a relationship with them. This term becomes increasingly sharp in the moments before the post-conflict local election or post-conflict local elections. There is a triangular relationship 
that is opposite between them. The relationship between the Bangka people, immigrants, and us Chinese people is quite good and is often conveyed in the slogan of our (Chinese) people about local indigenous people, including native immigrants with the term Pang-ngin Tong-in Jit Djong, which means that the Chinese and the Malays are the same. It is just that this relationship will feel even more distant just before the Pemilukada / Pilleg. In extreme cases, there is segregation where ethnicity, ethnicity, race, and religion become a commodity that is selling well in the arena to win a battle. The relationship patterns of the three ethnic groups appear different, as in the picture above. Political participation of the three ethnic groups, namely local natives, native immigrants, and Chinese ethnic groups, is the resistance between relationships as shown in the pattern of interaction between the three ethnic groups before the General Election / Regional Head General Election takes place. The relationship patterns of the three categories of ethnic groups were polarized into their internal groups.

The practice of dominating power can be caused by three things: the condition and position of ethnic groups, the position of ethnic-based political actors or actors, and the economic structure and relationships with powerful actors. Then articulated into the practice of dominating ethnic clan groups as follows: Political elites are the key actors in framing governance, be it the state, province, district, to rural areas. This is because actors are attached to the power [power] to be used, to plan, and to decide. For Bourdieu, the state represented by actors may be biased [subjective] in formulating development plans, issuing regional regulations, and so on. It is the habitus that Bourdieu (2010) defines as a form of prejudice that is inherent in individuals, such as assessing, making decisions, and evaluating their social world. The political identity at stake in the political arena is the production of habitus. This is because habitus is not formed scientifically but is born out of historical processes, cultural constructions, and political processes (Baños 2017). As political practices that prioritize ethnic, group, family, and clan identities have inherited a form of neo-feudalism that has disintegrated different groups (Djati 2010).

\section{CONCLUSION}

The ethnic identities of the people of the Bangka Belitung Islands Province can be grouped into three categories. The three groups include the indigenous ethnic group, the indigenous group of immigrants, and the Tinghoa ethnic group. In the political context in a multi-ethnic region, especially in the post-conflict local election / legislative election contestation, identifying ethnic identity is imperative. Actor in the arena to win the ethnic identity battle becomes a strategy in contestation. Factors supporting actors in winning the battle for power, maintaining, and even expanding power in the arena must be supported by capital, cultural capital, or symbolic capital (symbolic capital) and take advantage of primordial sentiments.

\section{REFERENCES}

1. Alamsyah, A. R. (2009). Pesantren, pendidikan kewargaan, dan demokrasi. Puslitbang Pendidikan Agama dan Keagamaan, Badan Litbang dan Diklat, Departemen Agama RI.

2. Aspinall, G. O. (Ed.). (2014). The polysaccharides. Academic Press.

3. Bourdieu, P. (2010). Arena produksi kultural: sebuah kajian sosiologi budaya.

4. Bourdieu, P., \& Nice, R. (1984). Distinction: A social critique of the judgement of taste (Vol. 306, No. 1, pp. 484-91). Cambridge, MA: Harvard university press.

5. Chambers, R. (1987). Pembangunan desa mulai dari belakang. Jakarta: LP3ES.

6. Denzin, N. K., \& Lincoln, Y. S. (Eds.). (2011). The Sage handbook of qualitative research. Sage.

7. Djati, W. R. (2014). Revivalisme Kekuatan Familisme dalam Demokrasi: Dinasti Politik di Aras Lokal. Masyarakat: Jurnal Sosiologi, 203-231

8. Esman MJ. 1994. Ethnic Politics. New York (US): Cornell University Press.

9. Fenton S. 1999. Ethnicity: Racism, Class and Culture. Lanham-Boulder- NewYork (USA): Rowman \& Littlefield Publishers, Inc. 
10. Huber, R. A., \& Headrick, A. M. (1999). Handwriting identification: facts and fundamentals. CRC press.

11. Miles, M. B., Huberman, A. M., \& Saldaña, J. (2018). Qualitative data analysis: A methods sourcebook. Sage publications.

12. Krisdinanto, N. (2016). Pierre Bourdieu, Sang Juru Damai. KANAL: Jurnal IImu Komunikasi, 2(2), 189-206.

13. Ruman, Y. S. (2011). Desentralisasi, Basis Sosial Dan Praktek Kekuasaan Elit Politik Di Tingkat Lokal Pasca Penerapan Otonomi Daerah. Humaniora, 2(1), 24-32.

14. Sarumpaet, B. A. M. (2012). Politik Identitas Etnis dalam Kontestasi Politik Lokal. Jurnal Kewarganegaraan, 19(2).

15. Sjaf S. 2014. Politik Etnik: Dinamika Politik Lokal di Kendari. Jakarta (ID): Yayasan Pustaka Obor.

16. Smith, G., \& Bouvier, H. (1993). Spontaneous migrant strategies and settlement processes in the plains and mountains.

17. Villacorta Baños, F. (2017). The field of fields. The state according to pierre bourdieu. 